\title{
Volatilization and leaching losses of nitrogen from different coated urea fertilizers
}

\author{
Priyanka Jadon ${ }^{2}$ Rajendiran Selladurai ${ }^{1, *}$ Shashi Singh Yadav ${ }^{2}$ Mounissamy Vassanda \\ Coumar $^{1}$ Mohan Lal Dotaniya ${ }^{1}$ Arvind Kumar Singh ${ }^{1}$ Jaideep Bhadouriya $^{1}$ SamareshKundu $^{1}$
}

${ }^{1}$ ICAR-Indian Institute of Soil Science, Nabibagh, Berasia Road, Bhopal (M.P.) - 462 038, India .

${ }^{2}$ Department of Soil Science and Agricultural Chemistry, Rajmata Vijayaraje Scindia Krishi Vishwa Vidyalaya, Gwalior (M.P.) - 474 002, India *Corresponding author: Rajendiran.S@icar.gov.in

\begin{abstract}
Fertilizers are one of the costly inputs in agriculture and development of nutrient efficient fertilizers is need of the hour. Keeping in view of the above, slow release coated urea fertilizers are developed and the N loss from different coated urea fertilizers in a Vertisol was studied in comparison with normal urea. The coated fertilizers used were neem, $4 \%$ pine oleoresin (POR), 35\% nano-rock phosphate and $2 \%$ nano-ZnO coated urea. In later two cases nanoparticles were loaded over $4 \%$ POR coated urea during preparation. Application of coated urea fertilizers such as neem coated urea and pine oleoresin coated urea in a Vertisol reduced the ammonia volatilization by $27.5 \%$ and $41.1 \%$, respectively. Similarly, reduction of $\mathrm{NO}_{3}-\mathrm{N}$ leaching due to application of neem, resin, nano-rock phosphate and nano- $\mathrm{ZnO}$ coated urea were $18.3 \%, 28.0 \%, 25.7 \%$ and $35.1 \%$, respectively. The reduction of $\mathrm{N}$ volatilization and leaching losses imparted by coated urea fertilizers could be a viable $\mathrm{N}$ source for crops. However field level validation experiments have to be carried out to assess the efficacy of these coated fertilizers in enhancing crop yield and nutrient use efficiency.
\end{abstract}

Keywords: Coated urea, pine oleoresin, neem oil, nanoparticles, ammonia volatilization, nitrate leaching.

\section{Introduction}

Nitrogen is one of the important primary nutrients for crop production. Indian soils particularly black soils of central India are generally low in available $\mathrm{N}$ (less than $125 \mathrm{mg} \mathrm{kg}^{-1}$ soil) due to poor organic matter content and high temperature. Due to low availability and easy loss/escape of $\mathrm{N}$ from soil, ex- ternal supply of $\mathrm{N}$ is vital for crop production and is being practiced across the world from long back. Among the nitrogenous fertilizers, urea is the most commonly used fertilizer in India and about 30.6 million metric tonnes (MMT) of urea is currently consumed which accounts $83 \%$ of total $\mathrm{N}$ fertilizer 
consumption in the country (IFA, 2015). Efficient use of nitrogen is absolutely essential for sustaining agriculture productivity as well as acting as a driving force for climate mitigation. Because of strong interrelationship among $\mathrm{N}$ uses, climate change and food security, there is an urgent need to search possibilities to increase $\mathrm{N}$ use efficiency under crop production. However, the $\mathrm{N}$ use efficiency of conventional chemical fertilizers is as low as 30 to $35 \%$ (Galloway and Cowling, 2002; Ladha et al., 2005). Therefore, improving $\mathrm{N}$ use efficiency of the fertilizers will be a major challenge.

In this connection, coating of urea is considered as one of the promising technologies and may act as efficient slow release $\mathrm{N}$ fertilizers (Dong et al., 2016). Previously, a lot of research work was done to test a number of coating material, containing urease and nitrification inhibitors, biodegradable polymers, and other polymers (Farmaha and Sims, 2013); but high cost and potent risks limit their field applications (Prasad, 2005; Prasad et al., 2007; Sivasakthy and Gnanavelrajah, 2012). However, currently only neem oil coated urea (NCU) is being manufactured and utilized in the country (Prasad, 2005) due to its low production cost. Still there is a possibility and scope for finding efficient naturally available cost effective coating materials for enhancing NUE. Keeping all the above in mind, the protocol has been developed to coat the urea with pine oleoresin (POR) (Kundu et al., 2013). Pine oleoresinis commercially extracted from pine tree (Pinus roxburghii) and is having empirical formula pimaric acid $\left(\mathrm{C}_{20} \mathrm{H}_{30} \mathrm{O}_{2}\right)$. The natural POR contains four resin acids, namely, levopimaric acid (22\%), palustric acid (11\%), Iabietic acid (10\%) and neoabietic acid (15\%). These acids are having antimicrobial properties. Coating urea with POR provides a physical barrier for slow release of $\mathrm{N}$ from urea may inhibit urease activity through antibacterial properties and may also reduce volatilization loss by acidifying alkaline micro-sites in soil (Kundu et al., 2013). All these above processes may contribute to the availability of $\mathrm{N}$ to the plants from POR coated urea. However, there is no any systemic data on $\mathrm{N}$ losses; uptake and use efficiency by plants under POR coated urea applications. Further, the detailed mechanisms and scientific information is lacking in regards with the behavior of the POR in soil and $\mathrm{N}$ losses through ammonia volatilization and leaching. Therefore, in the current investigation, it is aimed to study the $\mathrm{N}$ losses through ammonia volatilization and nitrate leaching from different coated urea fertilizers applied to soil.

\section{Materials and Methods}

\subsection{Soil collection and processing}

The experimental soil Vertisol (black cotton soil) was collected at the farm of Indian Institute of Soil Science $\left(23^{\circ} 18^{\prime} 33.6^{\prime \prime} \mathrm{N}, 77^{\circ} 24^{\prime} 27.2^{\prime \prime} \mathrm{E}\right.$ and $504 \mathrm{~m}$ above mean sea level), Bhopal, which is located in central part of India in the Madhya Pradesh state. It falls under semi-arid and sub-tropical zone characterized by hot summer and cold winter. Mean annual precipitation is about $1146 \mathrm{~mm}$, most of which is received during the monsoon period of July to September. The average maximum temperature during summer is $35^{\circ} \mathrm{C}$, while the average minimum temperature during winter is $4^{\circ} \mathrm{C}$. The bulk soil samples were collected from upper $15 \mathrm{~cm}$ of surface soil with an area of $1 \mathrm{~m}^{2}$. While collection all the stubbles, gravels and stones were removed. After collection, the samples were thoroughly mixed manually; shade dried; homogenized using wooden pestle; and mortar and passed through $2 \mathrm{~mm}$ size sieve. The important initial soil properties were analyzed following the standard analytical methods and listed in Table 1. 
Table 1. Physico-chemical characteristics of experimental soil

\begin{tabular}{|c|c|c|}
\hline Soil parameters & Mean \pm SD & Methods \\
\hline $\mathrm{pH}(1: 2.5$ soil/water ratio $)$ & $8.03 \pm 0.03$ & Jackson (1973) \\
\hline Electrical conductivity $\left(\mathrm{dS} \mathrm{m}^{-1}\right)$ & $0.08 \pm 0.08$ & Jackson (1973) \\
\hline \multicolumn{3}{|l|}{ (1:2.5 soil/water ratio) } \\
\hline Organic carbon $(\%)$ & $0.45 \pm 0.14$ & Walkley and Black (1934) \\
\hline Available nitrogen $\left(\mathrm{kg} \mathrm{ha}^{-1}\right)$ & $162 \pm 8.90$ & Subbiah and Asija (1956) \\
\hline Available phosphorus $\left(\mathrm{kg} \mathrm{ha}^{-1}\right)$ & $19.6 \pm 0.14$ & Olsen et al. (1954) \\
\hline Available potassium $\left(\mathrm{kg} \mathrm{ha}^{-1}\right)$ & $1050 \pm 26.3$ & Hanway and Heidel (1952) \\
\hline Available sulphur $\left(\mathrm{mg} \mathrm{kg}^{-1}\right)$ & $5.90 \pm 0.29$ & Chesnin and Yien (1950) \\
\hline \multicolumn{3}{|l|}{ DTPA extractable micronutrients } \\
\hline Copper(mg kg $\left.{ }^{-1}\right)$ & $0.95 \pm 0.24$ & \multirow{4}{*}{$\begin{array}{l}\text { Lindsay and } \\
\text { Norwell (1978) }\end{array}$} \\
\hline Zinc $\left(\mathrm{mg} \mathrm{kg}^{-1}\right)$ & $0.51 \pm 0.09$ & \\
\hline Iron $\left(\mathrm{mg} \mathrm{kg}^{-1}\right)$ & $10.5 \pm 0.10$ & \\
\hline Manganese $\left(\mathrm{mg} \mathrm{kg}^{-1}\right)$ & $8.80 \pm 0.85$ & \\
\hline
\end{tabular}

Note: SD - standard deviation

\subsection{Coated urea fertilizers used in the experiment}

The coated urea fertilizers used in the experiments were NCU, RCU, nano-ZnO (2\%) coated urea, and nano-rock phosphate $(35 \%)$ coated urea. The RCU was prepared using $4 \%$ crude POR dissolved in commercial petrol. Similarly, nano- $\mathrm{ZnO}$ and rock phos- phate coated fertilizers were prepared by over coating these materials on RCU (Kundu et al., 2016). Nano$\mathrm{ZnO}(<100 \mathrm{~nm})$ was obtained from Sigma-Aldrich and nano-RP $(<48.6 \mathrm{~nm})$ was prepared from Udaipur RP (34\% P2O5) using a high energy ball-mill.The nutritional composition of the fertilizer materials used in the study is given in Table 2 .

Table 2. Different fertilizer material used and their nutritional composition

\begin{tabular}{lccc}
\hline Material used & \multicolumn{3}{c}{ Nutrient content (\%) } \\
& $\mathrm{N}$ & $\mathrm{P}$ & $\mathrm{Zn}$ \\
\hline Urea & 46.0 & - & - \\
$\mathrm{RCU}$ & 44.3 & - & - \\
$\mathrm{NCU}$ & 46.0 & - & - \\
Nano ZnO coated urea & 43.0 & - & 1.45 \\
Nano Rock phosphate coated urea & 32.9 & 8.50 & - \\
& & & \\
\hline
\end{tabular}




\subsection{Laboratory experiments}

\subsubsection{Experimental setup of volatilization loss}

An incubation laboratory experiment was conducted to estimate volatilization loss of $\mathrm{NH}_{4}-\mathrm{N}$ from soil fertilized with different $\mathrm{N}$ sources using a force draft technique at ICAR-Indian Institute of Soil Science, Bhopal during 10-25 August, 2016. About $1 \mathrm{~kg}$ capacity of sealed plastic container was filled with $500 \mathrm{~g}$ (2 mm sieved) Vertisol. For this experiment soil was treated with $220 \mathrm{mg} \mathrm{N} \mathrm{kg}^{-1}$ through various $\mathrm{N}$ sources namely normal urea alone, and in combination with resin (1000 mg POR kg-1 soil), NCU and RCU; and also, absolute control (soil without any fertilizers) to know the emission from natural soil. Three replications were maintained for each treatment. Immediately after $\mathrm{N}$ spiking the container was closed and sealed properly using sticking material (gum) and paraffin films to avoid any leakage from the system. The closed dynamic (aerobic), air-flow system contained an air-exchange chamber (500 mL plastic box) and a trapping flask containing $20 \mathrm{~mL} 2 \%$ boric acid to absorb the volatilized ammonia. The stopper on each container was fitted with an inlet and outlet facility. The inlet was linked to an air pump and the outlet was connected by polyethylene tubing to the trapping flasks. Then periodic measurement of ammonia volatilized from each treatment was done after $24,72,96,120,144,168,192,216$ and $240 \mathrm{~h}$ by removing trapping flasks and the content in the flasks were titrated with standard acid. The loss of $\mathrm{NH}_{4}-\mathrm{N}$ after different periods from soil, coated and uncoated urea was calculated.

\subsubsection{Nitrate leaching experiment}

Experiment on leaching loss of $\mathrm{N}$ from various $\mathrm{N}$ sources that applied to soil was conducted using undisturbed transparent plastic columns in the laboratory condition at ICAR-Indian Institute of Soil Science, Bhopal during 1- 20 March, 2017. The treatments were 1. Control, 2. Normal urea, 3. NCU, 4. RCU, 5. Nano-rock phosphate coated urea and 6. Nano- $\mathrm{ZnO}$ coated urea. The amount of $\mathrm{N}$ applied in each treatment except control was $220 \mathrm{mg}$ $\mathrm{N}$. There were three replications maintained under each treatment.

Plastic transparent columns (size $60 \mathrm{~cm}$ height and $8 \mathrm{~cm}$ inner diameter) were used with assembly for leaching and collection of leachate. The columns were filled up to $15 \mathrm{~cm}$ with $2 \mathrm{~mm}$ sieved Vertisol (about $1.06 \mathrm{~kg}$ soil) and gently tapped to maintain the bulk density of $1.42 \mathrm{Mg} \mathrm{m}^{-3}$. The soil in the column was saturated with addition of $300 \mathrm{~mL}$ water and kept 2 days to reach water up to the bottom of the column. Then $220 \mathrm{mg} \mathrm{N}$ was applied on the top surface of soil in the column with different sources in respective treatments except control and about $200 \mathrm{~mL}$ distilled water was added immediately after fertilizer application and $4^{\text {th }}, 7^{\text {th }}, 10^{\text {th }}$ and $13^{\text {th }}$ days to all the columns/treatments. Leachates collected in $250 \mathrm{~mL}$ conical flasks were removed and analyzed periodically from $3,6,9,12$ and 15 days.

\subsubsection{Analysis of $\mathrm{NH}_{4}-\mathrm{N}$ and $\mathrm{NO}_{3}-\mathrm{N}$}

Ammonia volatilized from each treatment was absorbed using $2 \%$ boric acidand mixed indicator (methyl red and bromocresol green) solution. The amount of $\mathrm{NH}_{3}$ trapped was estimated by titrating with 0.02 
$N$ sulfuric acid (Subbaiah and Asija, 1956).For estimation of $\mathrm{NO}_{3}$-Ncontent in leachate, about $20 \mathrm{~mL}$ of leachate was taken in $100 \mathrm{~mL}$ beaker and was kept on a water both for evaporation till dryness, then it was kept for cooling, $3 \mathrm{~mL}$ of phenol-disulphonic acid and $15 \mathrm{~mL}$ of distilled water were added and mixed well with using glass rod and the content was transferred to $100 \mathrm{~mL}$ volumetric flask and 1:1 diluted ammonia solution was added till appearance of yellow colour, then thevolume was made upto $100 \mathrm{~mL}$. Similar practice was done by taking known standard solution of nitrates as well as blank using distilled water for colour development. Then measurements were made using spectrophotometer (model- CE2031) at $420 \mathrm{~nm}$ wavelength to measure the concentration of nitrate.

The percent loss of applied $\mathrm{N}$ through volatilization or leaching was calculated using Equation 1 as below:

Percent loss $=\frac{\text { Cumulative } \mathrm{N} \operatorname{Loss}_{\mathrm{T}}(\mathrm{mg})-\text { Cumulative N } \operatorname{Loss}_{\mathrm{C}}(\mathrm{mg})}{\text { Total }_{\mathrm{N}} \text { applied }(\mathrm{mg})} \times 100$

Where, ${ }_{T}$ and ${ }_{\mathrm{C}}$ represents treated and control soil, respectively.

\subsection{Statistical analysis}

The data pertaining to volatilization and leaching losses of $\mathrm{N}$ had been instructed to statistical analysis adopting completely randomized block design (CRD) (Panse and Sukhatme, 1967). One-way analysis of variance (ANOVA) was done using statistical package SPSS version 9.1.6.3. Further the significant difference between treatments means were compared with critical differences at $5 \%$ confidence level.

\section{Results}

\subsection{Volatilization loss of $N$}

The amount of $\mathrm{N}$ volatilized from Vertisol treated with different $\mathrm{N}$ sources at different time intervals and the percentage of loss are summarized in Table 3. It was found that the rate of $\mathrm{NH}_{4}-\mathrm{N}$ volatilization loss for incubation period under control, normal urea, NCU, RCU and urea + POR applied soil varied from $0.30-1.45,2.10-18.40,2.65-11.80,1.82$ 9.45 and $2.45-12.50 \mathrm{mg} \mathrm{N}$ pot $^{-1} \mathrm{~d}^{-1}$, respectively. Invariable to $\mathrm{N}$ sources, after third day there was significant increment in volatilization rate and attained maximum at $5^{\text {th }}$ and $6^{\text {th }}$ day and there after followed the declining trend. The rate of ammonia volatilization was highest for normal urea applied soils from day one to $7^{\text {th }}$ day and $8-10^{\text {th }}$ day NCU applied soils had the highest ammonia volatilization rate. In initial stages (upto 7 days) ammonia volatilization was higher in normal urea applied soil and thereafter coated urea fertilizers applied treatments had the higher volatilization. Further the cumulative ammonia volatilization loss at different time has been displayed in Figure 1.

The total amount of $\mathrm{NH}_{3}-\mathrm{N}$ volatilized from normal urea, NCU and RCU after $240 \mathrm{~h}$ was 82.4 , 62.5 and $52.6 \mathrm{mg} \mathrm{N}^{-1}$, respectively and were significantly differ from each other. The percent of $\mathrm{NH}_{3}-\mathrm{N}$ volatilized from applied $\mathrm{N}$ under these treatments were $32.9 \%, 23.9 \%$ and $19.4 \%$, respectively (Table 3). Further application of POR as solution along with normal urea also showed $\mathrm{NH}_{3}-\mathrm{N}$ volatilization loss of $66.4 \mathrm{mg} \mathrm{N}$ pot $^{-1}(25.7 \% \mathrm{~N}$ loss from applied $\mathrm{N}$ ). 
Table 3. Volatilization loss of $\mathrm{N}$ from different $\mathrm{N}$ sources applied to a Vertisol

\begin{tabular}{|c|c|c|c|c|c|c|c|c|c|c|c|c|}
\hline \multirow{2}{*}{ Treatment } & \multicolumn{11}{|c|}{$\mathrm{NH}_{3}-\mathrm{N}$ volatilization rate $\left(\mathrm{mg} \mathrm{N} \mathrm{pot}^{-1}\right)$} & \multirow{2}{*}{$\begin{array}{c}\text { Percent loss of } \\
\text { applied N through } \\
\text { volatilization within } \\
10 \text { days period }\end{array}$} \\
\hline & $24 \mathrm{~h}$ & $48 \mathrm{~h}$ & $72 \mathrm{~h}$ & $96 \mathrm{~h}$ & $120 \mathrm{~h}$ & $144 \mathrm{~h}$ & $168 \mathrm{~h}$ & $192 \mathrm{~h}$ & $216 \mathrm{~h}$ & $240 \mathrm{~h}$ & $\begin{array}{l}\text { Cumulative } \\
\text { loss }\end{array}$ & \\
\hline Control & $1.45^{\mathrm{e}}$ & $0.92^{\mathrm{e}}$ & $1.05^{\mathrm{e}}$ & $0.70^{\mathrm{e}}$ & $1.71^{\mathrm{d}}$ & $1.62^{\mathrm{e}}$ & $1.01^{\mathrm{e}}$ & $0.73^{\mathrm{c}}$ & $0.59^{\mathrm{c}}$ & $0.32^{\mathrm{e}}$ & $9.9^{\mathrm{e}}$ & - \\
\hline Normal urea & $3.25^{\mathrm{a}}$ & $3.45^{\mathrm{a}}$ & $3.95^{\mathrm{a}}$ & $8.41^{\mathrm{a}}$ & $16.0^{\mathrm{a}}$ & $18.4^{\mathrm{a}}$ & $12.3^{\mathrm{a}}$ & $8.09^{\mathrm{a}}$ & $6.40^{\mathrm{b}}$ & $2.11^{\mathrm{d}}$ & $82.4^{\mathrm{a}}$ & 32.9 \\
\hline $\mathrm{NCU}$ & $2.65^{\mathrm{b}}$ & $2.81^{\mathrm{b}}$ & $2.70^{\mathrm{b}}$ & $4.72^{\mathrm{c}}$ & $11.9^{\mathrm{b}}$ & $8.12^{\mathrm{c}}$ & $8.51^{\mathrm{c}}$ & $8.28^{\mathrm{a}}$ & $7.18^{\mathrm{a}}$ & $5.74^{\mathrm{a}}$ & $62.5^{\mathrm{c}}$ & 23.9 \\
\hline $\mathrm{RCU}$ & $1.80^{\mathrm{d}}$ & $2.01^{\mathrm{d}}$ & $1.75^{\mathrm{d}}$ & $4.11^{\mathrm{d}}$ & $9.46^{\mathrm{c}}$ & $4.35^{\mathrm{d}}$ & $8.69^{\mathrm{d}}$ & $8.19^{\mathrm{a}}$ & $7.30^{\mathrm{a}}$ & $4.89^{\mathrm{b}}$ & $52.6^{\mathrm{d}}$ & 19.4 \\
\hline Urea + POR & $2.45^{\mathrm{c}}$ & $2.53^{\mathrm{c}}$ & $2.85^{\mathrm{c}}$ & $6.20^{\mathrm{b}}$ & $12.5^{\mathrm{b}}$ & $11.8^{\mathrm{b}}$ & $10.1^{\mathrm{b}}$ & $7.40^{\mathrm{b}}$ & $6.19^{\mathrm{b}}$ & $4.40^{\mathrm{c}}$ & $66.4^{\mathrm{b}}$ & 25.7 \\
\hline$C D(P=0.05)$ & 0.13 & 0.18 & 0.21 & 0.53 & 1.01 & 1.24 & 0.80 & 0.62 & 0.53 & 0.42 & 5.13 & - \\
\hline
\end{tabular}

Note: Amount of soil in pot was $500 \mathrm{~g}$ and $\mathrm{N}$ applied @ $220 \mathrm{mg} \mathrm{N} \mathrm{pot}^{-1}$; Data followed by same letter in a column indicates there is no significant difference between/among the treatments at $\mathrm{P}=0.05$.

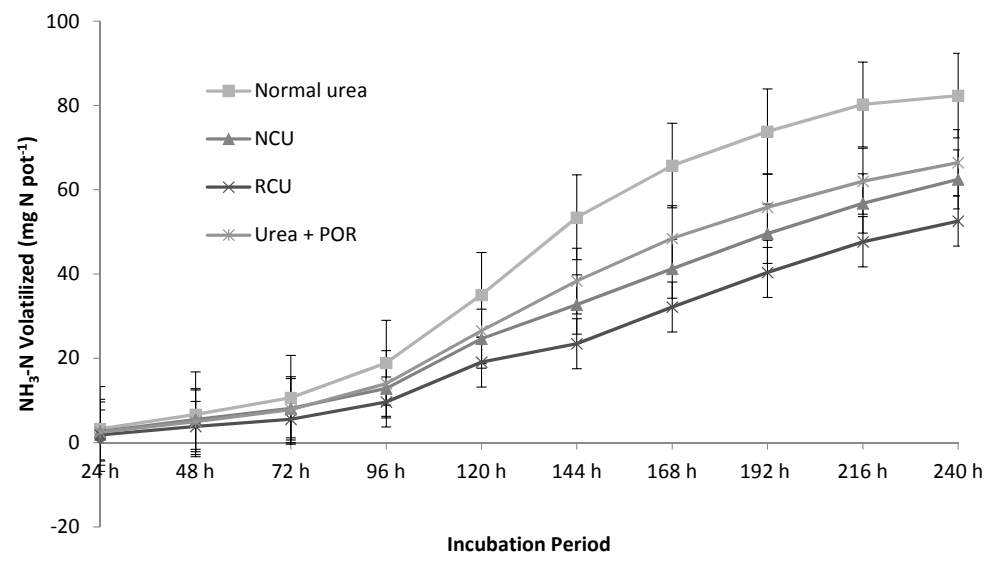

Figure 1. Cumulative volatilization loss of $\mathrm{NH}_{3}-\mathrm{N}$ from different $\mathrm{N}$ sources applied to a Vertisol.

\subsection{Nitrate leaching}

The amount of $\mathrm{NO}_{3}-\mathrm{N}$ leached from the soil treated with different $\mathrm{N}$ fertilizers at different time intervals has been revealed in Table 4. Invariable to $\mathrm{N}$ source, application of $\mathrm{N}\left(220 \mathrm{mg}\right.$ column $\left.{ }^{-1}\right)$ tremendously increased the $\mathrm{NO}_{3}-\mathrm{N}$ leaching from soil. Further the nitrate leaching was high in the initial stages of incubation period after application of $\mathrm{N}$ fertilizers. The highest nitrate leaching rate was observed in first three days, and then it followed the declining trend upto the end of incubation period. However, the rate and amount of nitrate leaching from different $\mathrm{N}$ fertilizers applied soils at different time varied. For first 6 days the rate of nitrate leaching loss was highest in normal urea applied soils. Then in the later stages nano- $\mathrm{ZnO}$ coated urea had the highest nitrate leaching rates. The cumulative loss of $\mathrm{N}$ through leaching from soil treated with different $\mathrm{N}$ sources has been displayed in Figure 3. The t otal amount of $\mathrm{NO}_{3}-\mathrm{N}$ leached from the soil treated with urea, NCU, nano- 
rock phosphate coated urea, $\mathrm{RCU}$, nano-ZnO coated urea and control were 130.0, 110.0, 99.9, 102.0, 92.3 and $23.0 \mathrm{mg} \mathrm{NO}_{3}-\mathrm{N} \mathrm{kg}^{-1}$ soil, respectively. There was significant difference observed between coated fertilizers and normal urea applied soil in respect to total amount of $\mathrm{NO}_{3}$-Nleached during the study period. Further, there was significant difference observed between RCU and NCU applied soil in total amount of nitrate leaching. Among the different $\mathrm{N}$ sources applied, the nano- $\mathrm{ZnO}$ coated urea fertilizer applied soil had the lowest total nitrate leaching and was significantly differ from other $\mathrm{N}$ sources applied treatments. The percent loss of applied N (220 mg) through nitrate leaching for urea, NCU, rock phosphate coated urea, $\mathrm{RCU}$, nano-ZnO coated urea were $48.5 \%, 39.7 \%$, $34.9 \%, 36.0 \%$ and $31.5 \%$, respectively (Table 4 ).

Table 4. Leaching loss of $\mathrm{N}$ in the form of $\mathrm{NO}_{3}-\mathrm{N}$ from different $\mathrm{N}$ sources applied to a Vertisol

\begin{tabular}{|c|c|c|c|c|c|c|c|}
\hline \multirow{2}{*}{ Treatment } & \multicolumn{6}{|c|}{ Nitrate-N leaching loss (mg N kg${ }^{-1}$ soil) } & \multirow{2}{*}{$\begin{array}{c}\text { Percent } N \text { loss of } \\
\text { applied } N \text { through } \\
\text { leaching within } \\
15 \text { days period }\end{array}$} \\
\hline & $3 \mathrm{~d}$ & $6 \mathrm{~d}$ & $9 \mathrm{~d}$ & $12 \mathrm{~d}$ & $15 \mathrm{~d}$ & loss & \\
\hline Control & $14.0^{\mathrm{e}}$ & $6.31^{\mathrm{e}}$ & $1.81^{\mathrm{f}}$ & $0.59^{\mathrm{e}}$ & $0.31^{\mathrm{de}}$ & $23.0^{\mathrm{e}}$ & - \\
\hline Normal urea & $86.0^{\mathrm{a}}$ & $38.8^{\mathrm{a}}$ & $3.24^{\mathrm{e}}$ & $1.23^{\mathrm{cd}}$ & $0.49^{\mathrm{c}}$ & $130^{\mathrm{a}}$ & 48.5 \\
\hline $\mathrm{NCU}$ & $71.1^{\mathrm{b}}$ & $33.1^{\mathrm{b}}$ & $4.31^{\mathrm{d}}$ & $1.5^{\mathrm{c}}$ & $0.35^{\mathrm{d}}$ & $110^{\mathrm{b}}$ & 39.7 \\
\hline Rock phosphate coated urea & $59.9^{\mathrm{c}}$ & $20.3^{\mathrm{d}}$ & $12.7^{\mathrm{a}}$ & $6.43^{\mathrm{b}}$ & $0.62^{\mathrm{b}}$ & $99.9^{\mathrm{c}}$ & 34.9 \\
\hline $\mathrm{RCU}$ & $67.1^{\mathrm{b}}$ & $29.2^{\mathrm{c}}$ & $5.11^{\mathrm{c}}$ & $0.62^{\mathrm{de}}$ & $0.29^{\mathrm{e}}$ & $102^{\mathrm{c}}$ & 36.0 \\
\hline Nano $\mathrm{ZnO}$ coated urea & $54.3^{\mathrm{d}}$ & $18.2^{\mathrm{d}}$ & $10.3^{b}$ & $8.57^{\mathrm{a}}$ & $0.93^{\mathrm{a}}$ & $92.3^{\mathrm{d}}$ & 31.5 \\
\hline$C D(P=0.05)$ & 4.45 & 2.14 & 0.78 & 0.63 & 0.05 & 6.65 & - \\
\hline
\end{tabular}

Note: Amount of soil used in each column 1.0 kg and N applied @220 mg N column-1; Data followed by same letter in a column indicates there is no significant difference between/among the treatments at $\mathrm{P}=0.05$.

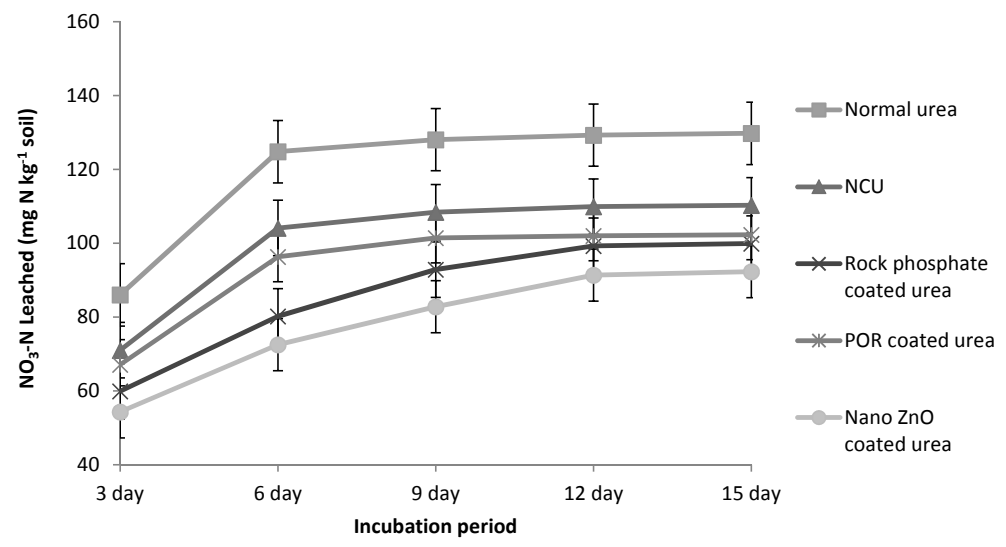

Figure 2. Cumulative leaching loss of $\mathrm{NO}_{3}-\mathrm{N}$ from different $\mathrm{N}$ sources applied to a Vertisol 


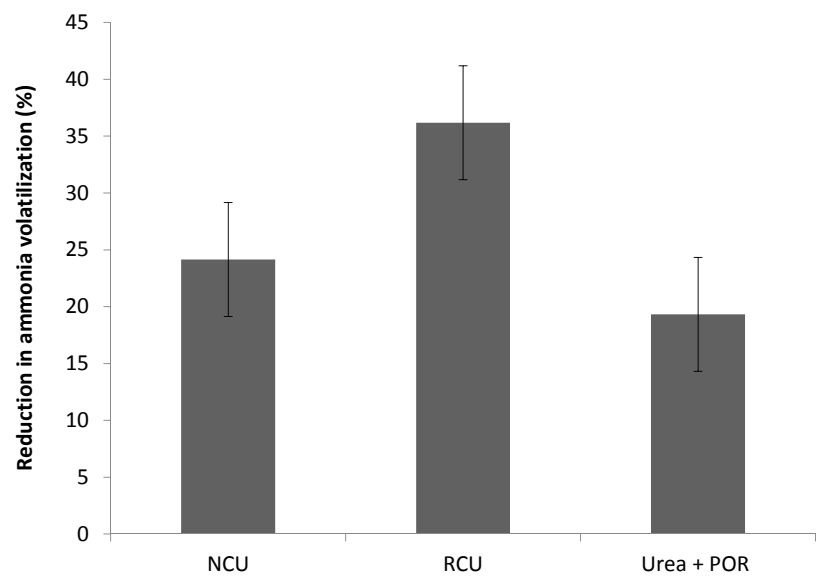

Figure 3. Percent reduction in ammonia volatilization loss from soil treated with coated urea fertilizers, urea plus pine oleoresin in comparison with urea

\section{Discussion}

Ammonia volatilization in coated urea fertilizers applied treatments were significantly lower than that of normal urea applied treatments. The findings were in concurrence with results reported by many workers (Kundu et al., 2013; Junejo et al., 2012; Junejo et al., 2011; Wang et al., 2007). Among the coated fertilizer, RCU reduced significantly low $\mathrm{NH}_{3}-\mathrm{N}$ loss than the NCU. This might be due to slow release of $\mathrm{N}$ from coated urea fertilizers because it might have acted as physical barrier. Further, the antimicrobial properties and microsite $\mathrm{pH}$ changes due to POR caused the reduction in urea hydrolysis by inhibiting urease-producing microbes (Junejo et al., 2012; Kundu et al., 2013). Also it was demonstrated that time required for hydrolysis of $90 \%$ of the applied urea had markedly increased from 88.56 to $328.94 \mathrm{~h}$ in the presence of pine oleoresin (Kundu et al., 2013). Moreover, presence of phenolic compounds and aromatic ketones in POR might have reduced the enzyme-substrate reaction rate by binding with the urease (Patra and Jain, 1993; Ghosh et al., 2002). The percent reduction in volatilization loss from NCU, RCU and urea+ POR applied soil over normal urea applied soil was $24.2 \%, 36.2 \%$, and $19.3 \%$, respectively (Figure 3 ). In case of neem coated urea, alkaloid present in the neem oil might have inhibited the urease producing microbial activities resulted in low urea hydrolysis rate reduced the $\mathrm{NH}_{3}-\mathrm{N}$ loss (Prasad et al., 2007, Prasad et al., 2001; Suri et al., 2000). The ammonia volatilization from applied fertilizers for initial two days was very low and then increase from third day to seventh day there after it was decreased. This might be due to conversion of urea to ammonia might have taken two days. However in all the stages rate of $\mathrm{NH}_{3}-\mathrm{N}$ loss from coated urea fertilizers were lower than that of normal urea. Application of the different coated urea fertilizers in a Vertisol has significantly reduced the nitrate leaching losses than the normal urea in this study. Due to the hydrophobic nature and the antimicrobial properties 
of POR (Kundu et al., 2013) and neem oil (Baboo, 2014; Singh, 2016), coated ureas were slowly dissolved and was gradually mineralized by microbes. Similarly, coating phosphate fertilizers with organic acids improved $\mathrm{P}$ availability and maize yield (Teixeira et al., 2016). The trend of nitrate leaching from different $\mathrm{N}$ sources applied to soil was observed as follow: nano- $\mathrm{ZnO}$ coated urea $<$ rock phosphate coated urea $<\mathrm{RCU}<\mathrm{NCU}<$ normal urea. The percent reduction in nitrate leaching from different coated urea fertilizer when compared to normal urea depicted in Figure 4. The reduction in $\mathrm{NO}_{3}-\mathrm{N}$ leaching due to neem, resin, rock phosphate and nano- $\mathrm{ZnO}$ coatings were $18.3 \%, 28.0 \%, 25.7 \%$ and $35.1 \%$, respectively. The lowest leaching losses from nano-ZnO coated urea might be antimicrobial properties of nano- $\mathrm{ZnO}$ particles (Espitia et al., 2012; Singh and Nanda, 2013) that might have influenced the microbial activities that resulted in a reduction of the rates of urea hydrolysis and nitrification processes. Several researchers reported the antibacterial activities of nano- $\mathrm{ZnO}$ over a wide spectrum of bacterial species (Buzea et al., 2007; Nair et al., 2011; Raghupathi et al., 2011). Importance of particle size, morphology and concentration of $\mathrm{ZnO}$ nanoparticles in enhancing the antimicrobial properties had also been reported (Sirelkhatim et al., 2015). However, this was beyond the scope of the current investigation and might be studied further. Similarly low nitrate leaching from RP coated urea could be due to enlarged coating over POR that acted as a physical barrier that reduced the release and availability of $\mathrm{N}$ for microbes. Also, the presence of high concentration of RP nanoparticles might have enhanced the interaction and reactivity of these particles with microbes preventing microbial activities and microbial-mediated nitrification process (Kundu et al., 2016). Further coated fertilizers could enhance the nutrient availability and yield of crops (Dong et $a l ., 2016)$ and improve water use efficiency of production system (Zhang et al., 2017) by their slow releasing capacity and prolonging the duration of available nutrients in soil.

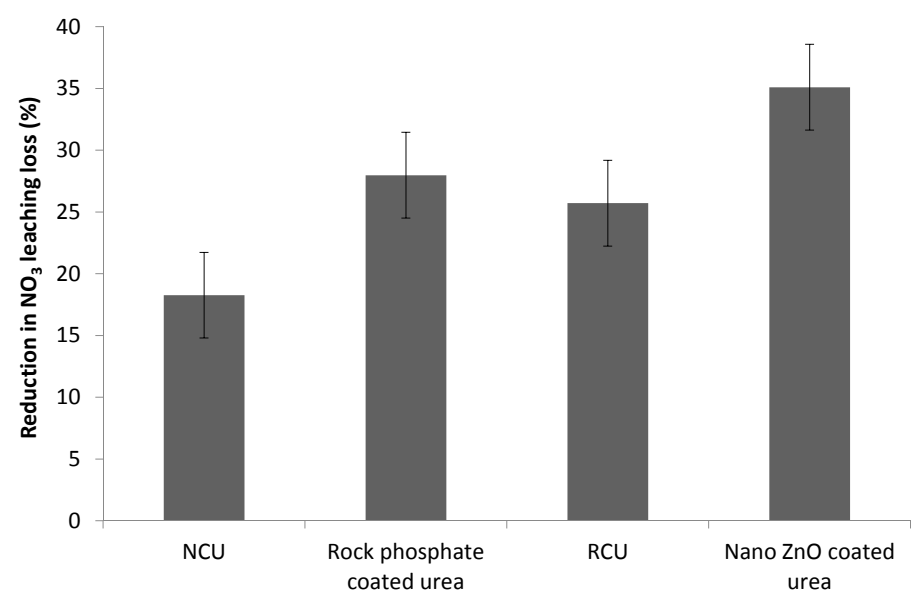

Figure 4. Percent reduction in nitrate-N leaching loss from soil treated with various coated urea fertilizers over urea. 


\section{Conclusions}

Application of coated urea fertilizers significantly reduced the $\mathrm{N}$ losses through ammonia volatilization and nitrate leaching. Therefore, the reduction of $\mathrm{N}$ losses, imparted by coated urea fertilizers could be a viable $\mathrm{N}$ source for crops. Moreover,it indicates that resin coated urea could be a good alternative $\mathrm{N}$ source against neem oil coated urea that is largely in practice in India at present. However field level validation experiments have to be carried out to assess the efficacy of these coated fertilizers in enhancing crop yield and nutrient use efficiency before familiarizing to farming community.

\section{References}

Baboo, P. 2014. Neem oil and neem coated urea. Technical Paper, November 2014, available at: www.ureaknowhow.com. $7 \mathrm{p}$.

Buzea, C., Pacheco, I.I., Robbie, K. 2007. Nanomaterials and nanoparticles: sources and toxicity. Biointerphases 2, 17-71.

Chesnin, L., Yien, C.H. 1950. Turbidimetric determination of available sulfate. Soil Sci. Soc. Am. Proc. 15, 149-151.

Espitia, P., Soares, N.D.F., Coimbra, J.S.D.R., Andrade, N.J., Cruz, R.S., Medeiros, E.A.A. 2012. Zinc oxide nanoparticles: Synthesis, antimicrobial activity and food packaging applications. Food Bioprocess Technol. 5, 1447-1464.

Dong, Y.J., He, M.R., Wang, Z.L., Chen, W.F., Hou, J., Qiu, X.K., Zhang, J.W. 2016. Effects of new coated release fertilizer on the growth of maize. J. Soil Sci. Plant Nutr. 16, 637-649.

Farmaha, B.S., Sims, A.L. 2013. Yield and protein response of wheat cultivars to polymer-coated urea and urea, Agron. J. 105, 229-236.
Galloway, J.N., Cowling, E.B. 2002. Reactive nitrogen and the world: 200 years of change. AMBIO: A J. Human Environ.31, 64-71.

Ghosh, B.N., Chowdhury, H., Kundu, S., Gupta, H.S 2002. Effect of pine needle (Pinus roxburghii) and chinaberry (Melia azaderach) seed extracts on urea hydrolysis rate in a sandy soil. J. Indian Soc. Soil Sci. 50, 309-311.

Hanway, J.J., Heidel, H. 1952. Soil analysis methods as used in Iowa state college soil testing laboratory. Iowa Agric. 57, 1-31.

IFA. 2015. International Fertilizer Industry Association Statistics. Available at: http://www.fertilizer. org/ifadata; accessed 18/3/2017.

Jackson, M.L. 1973. Soil chemical analysis. Prentice Hall of India Private Limited,New Delhi, India. $498 \mathrm{p}$.

Junejo, N., Khanif, M.Y., Dharejo, K.A., Hazandy Abdul-Hamid, Arifin Abdu. 2012. Evaluation of coated urea for ammonia volatilization loss, nitrogen mineralization and microsite $\mathrm{pH}$ in selected soil series. African J. Biotechnol. 11, 366-378.

Junejo, N., Khanif, M.Y., Dharejo, K.A., Hazandy Abdul-Hamid, Arifin Abdu. 2011. A field evaluation of coated urea with biodegradable materials and selected urease inhibitors. African J. Biotechnol. 10, 19729-19736.

Kundu S., Adhikari, T., Mohanty, S.R., Rajendiran, S., Vassanda Coumar, M., Saha, J.K., Patra, A.K. 2016. Reduction in nitrous oxide emission from nano zinc oxide and nano rock phosphate coated urea. Agrochimica 60, 59-70.

Kundu, S., Adhikari, T., Vassanda Coumar, M., Rajendiran, S., Bhattacharya, R., Saha, J.K., Biswas, A.K., Subba Rao, A. 2013. Pine oleoresin: a potential urease inhibitor and coating material for slow release urea. Curr. Sci. 104, 1068-1071. 
Ladha, J.K., Pathak, H., Krupnik T.J., Six J., Kessel, C.V. 2005. Efficiency of fertilizer nitrogen in cereal production: retrospect and prospects. Adv. Agron. 87, 85-176.

Lindsay, W.L., Norvell, W.A. 1978. Development of DTPA soil test for zinc, iron, manganese and copper. Soil Sci. Soc. America J. 42, 421-428.

Nair, M.G., Nirmala, M., Rekha, K., Anukaliani, A. 2011. Structural, optical, photo catalytic and antibacterial activity of $\mathrm{ZnO}$ and $\mathrm{Co}$ doped $\mathrm{ZnO}$ nanoparticles. Material Lett. 65, 1797-1800.

Olsen, S.R., Cole, C.V., Watanabe, F.S., Dean, L.A. 1954. Estimation of available phosphorus in soils by extraction with sodium bicarbonate. USDA Circular, 939. US government printing office, Washington, DC.

Panse, V.G., Sukhatme, P.V. 1967. Statistical Methods for Agricultural Workers. ICAR,New Delhi, India. $381 \mathrm{p}$.

Patra, A.K., Jain, J.M. 1993. Transformation of a coal fertilizer ammonium polycarboxylate and potentialities of coal producednitrification inhibitors. J. Indian Soc. Soil Sci. 41, 38-41.

Prasad, R., Sharma, S.N., Singh, S., Saxena, V.S., Devakumar, C. 2001. Pusa neem emulsion as an eco-friendly coating agent for urea quality and efficiency. Fert. News 46, 73-74.

Prasad, R., Shivay, Y.S., Kumar, D., Sharma, S.N., Devakumar, C. 2007. Neem for sustainable agriculture and the environment. Proc. Nat. Acad. Sci. India Sec. B77, 313-330.

Prasad, R. 2005. Research of nitrification inhibitors and slow release nitrogen fertilizer in India: A review. Proc. Nat. Acad. Sci. India Sec. B75, 149-157.
Raghupathi, K.R., Koodalir, T.,Manna, A.C. 2011. Size-dependent bacterial growth inhibition and mechanism of antibacterial activity of zinc oxide nanoparticles. Langmuir 27, 4020-4028.

Singh, B. 2016. Agronomic Benefits of Neem Coated Urea - A Review.Technical Report, Indian Fertilizer Association. doi: 10.13140/ RG.2.2.10647.98722.

Singh, P., Nanda, A. 2013. Antimicrobial and antifungal potential of zinc oxide nanoparticles in comparison to conventional zinc oxide particles. J. Chem. Pharmaceut. Res. 5, 457-463.

Sirelkhatim, A., Mahmud, S., Seeni, A., Kaus, N.H.M., Ann, L.C., Bakhori, S.K.M., Hasan, H., Mohamad, D. 2015. Review on zinc oxide nanoparticles: antibacterial activity and toxicity mechanism. Nano-Micro Lett. 7, 219-242.

Sivasakthy, K., Gnanavelrajah, N. 2012. Organic nitrogen sources and nitrification inhibitors on leaching and phyto-accumulation of nitrate and yield of Amaranthus polygamous. World J. Agric. Sci. 8, 208-211.

Subbiah, B.V., Asija, G.L. 1956. A rapid procedure for estimation of available nitrogen in soils. Curr. Sci. $25,259-260$.

Suri, I.K., Mathews, S., Saxena, V.S. 2000. Coating of prilled urea with neem - trial at KRIBHCO's Hazira plant. Fert. News 45, 17-22.

Teixeira, R.S., da Silva, I.R., de Sousa, R.N., Mattiello, E.M., Soares, E.M.B. 2016. Organic acid coated-slow-release phosphorus fertilizers improve P availability and maize growth in a tropical soil. J. Soil Sci. Plant Nutr. 16, 1097-1112. 
Walkley, A., Black, I.A. 1934. An examination of Degtjareff method for determining soil organic matter and a proposed modification of the chromic acid titration method. Soil Sci. 37, 29-38.
Wang, X.Z., Zhu, J.G., Gao, R., Yasukazu, H., Feng, K. 2007. Nitrogen cycling and losses under ricewheat rotations with coated urea and urea in the Taihu Lake Region. Pedosphere 17, 62-69.

Zhang, H., Yu, X., Jin, Z., Zheng, W., Zhai, B., Li, Z. 2017. Improving grain yield and water use efficiency of winter wheat through a combination 